\title{
Advanced Head and Neck Cancer: Long-Term Results of Chemo-Radiotherapy, Complications and Induction of Second Malignancies
}

\author{
R. Munker ${ }^{\mathrm{a}} \quad$ L. Purmale ${ }^{\mathrm{a}}$ \\ R. Hartenstein ${ }^{a}$ \\ Ü. Aydemirc \\ M. Reitmeier ${ }^{\mathrm{a}}$ \\ H. Pohlmanna \\ H. Schorer ${ }^{b}$ \\ aIV. Medizinische Abteilung (Tumorzentrum), \\ ${ }^{b}$ Abteilung Strahlen-Onkologie, Städtisches Krankenhaus München-Harlaching, \\ ${ }^{c}$ Abteilung Biometrie und Epidemiologie, Ludwig-Maximilians-Universität, München
}

\section{Key Words}

Head and Neck Cancer . Chemo-radiotherapy .

Second malignancies · Late effects

\section{Summary}

Background: Chemo-radiotherapy is superior to radiotherapy alone in the treatment of advanced, inoperable head and neck cancer. The long-term treatment results, the induction of second malignant tumors, and other long-term toxicities are not well defined. Patients and Methods: 100 consecutive patients with advanced head and neck cancer who were treated at our center were studied. Treatment results, survival, the occurrence of late complications, and second malignant tumors (SMT) were investigated. 78 patients were treated with a protocol combining cisplatinum, 5-fluorouracil, folinic acid and hyperfractionated irradiation. 22 patients were treated with other chemo-radiotherapy protocols. The relative risk of developing an SMT was compared with that within the normal population. Results: The cumulative total probability of survival was $51.1 \%$ at 2 years and $38.7 \%$ at 4 years. The probability of relapse-free survival was $39.9 \%$ at 2 years and $36.7 \%$ at 4 years. A total of 7 patients developed SMT (4 cases of lung cancer, 2 colon cancers, 1 skin cancer). After 6 years, a cumulative risk of SMT of $8.7 \%$ was observed. The relative risk of developing an SMT was significantly increased (4.45-fold in males) compared with a normal population. 13 of 38 evaluable patients $(34.2 \%)$ had severe late complications like fibrosis of soft tissues, nerve lesions, or were dependent on tracheal cannulas. Conclusions: The treatment results and long-term prognoses in our population of unselected high-risk patients are unsatisfactory, but comparable to those from multicenter studies. About $35 \%$ of patients become long-term ( $>4$ years) survivors. SMT generally occur early, have a poor prognosis and, most likely, are not treatment-related. Approximately $30 \%$ of long-term survivors have severe, often incapacitating late effects. The treatment and - if possible - prevention of these late effects is important for the quality of life of patients who survived advanced head and neck cancer.
Schlüsselwörter

Kopf-Hals-Tumoren - Chemoradiotherapie - Zweitmalignome . Spätfolgen

\section{Zusammenfassung}

Hintergrund: Bei der Behandlung fortgeschrittener, inoperabler Kopf-Hals-Tumoren gilt die kombinierte Chemoradiotherapie für ausgewählte Patienten als Standard und zeigt bessere Ergebnisse als eine alleinige Strahlentherapie. Die langfristigen Ergebnisse dieser Therapie, die Induktion von Zweitmalignomen (ZWM) und andere Spättoxizitäten sind in der Literatur nicht genau definiert. Patienten und Methoden: Ausgewertet wurden 100 konsekutive Patienten mit fortgeschrittenen Kopf-Hals-Tumoren, die an unserem Zentrum behandelt wurden. Untersucht wurden die Behandlungsergebnisse, das Auftreten von Spätkomplikationen und von ZWM. 78 Patienten wurden nach einem Protokoll behandelt, das Cisplatin, 5-Fluorouracil, Folinsäure und hyperfraktionierte Bestrahlung kombinierte. $22 \mathrm{~Pa}$ tienten wurden nach anderen Chemoradiotherapie-Protokollen behandelt. Das relative Risiko, ein ZWM zu entwickeln, wurde mit dem Risiko in der Normalbevölkerung verglichen. Ergebnisse: Die kumulative Gesamtüberlebenswahrscheinlichkeit nach 2 Jahren war 51,1\% und nach 4 Jahren 38,7\%. Die Wahrscheinlichkeit des rezidivfreien Überlebens betrug 39,9\% nach 2 Jahren und $36,7 \%$ nach 4 Jahren. Insgesamt entwickelten $7 \mathrm{~Pa}-$ tienten ZWM (4 Fälle von Lungenkrebs, 2 Fälle von Darmkrebs, 1 Hautkrebs). Nach 6 Jahren wurde ein kumulatives Risiko von ZWM von 8,7\% beobachtet. Das relative Risiko, an einem ZWM zu erkranken, war gegenüber der Normalbevölkerung signifikant erhöht (4,45-fach bei Männern). 13 von 38 auswertbaren Patienten $(34,2 \%)$ zeigten bei der letzten Kontrolle ernste Spätfolgen wie narbige Fibrose, Läsionen der Nerven an Hals oder Schulter, oder brauchten weiterhin eine Trachealkanüle. Schlussfolgerungen: Die Behandlungsergebnisse und die langfristigen Prognosen unserer unselektionierten Hochrisikopatienten sind unbefriedigend, aber vergleichbar mit den Ergebnissen multizentrischer Studien. Rund 35\% der Patienten überleben längerfristig (> 4 Jahre). ZWM treten im allgemeinen früh auf, haben eine schlechte Prognose und sind mit überwiegender Wahrscheinlichkeit nicht therapiebedingt. Rund 30\% der Langzeitüberlebenden zeigen ernste, oft zu Invalidität führende Spätfolgen. Die Behandlung und - falls möglich - die Prävention dieser Spätfolgen ist wesentlich für die Lebensqualität der Patienten, die fortgeschrittene Kopf-Hals-Tumoren überlebt haben. 


\section{Introduction}

In the 1980s, patients with locoregionally advanced head and neck cancer had a poor prognosis. Conventional therapy, surgery and radiation, led to long-term survival or even cure in fewer than $20 \%$ of patients. The introduction of platinumbased chemo-radiotherapy has improved the response and possibly the cure rate of patients with advanced head and neck cancer and can now be considered as the standard of care [1-3]. The rationale of chemo-radiotherapy with hyperfractionated irradiation is that tumor cells are sensitized to radiation and thereby the resistance of tumor cells is overcome. A meta-analysis of 63 trials concluded that chemotherapy added to locoregional treatment provided a benefit in survival rate of $4 \%$ at 2 and at 5 years [4]. It is known that modern chemo-radiotherapy entails a considerable acute toxicity (e.g. mucositis) and some long-term complications like radiation fibrosis and xerostomia. In addition, the treatment of patients with head and neck cancer is complicated by comorbidity. If all types of cancer are considered, the induction of second malignant tumors (SMT) is a serious problem [5]. For example, the long-term treatment results of patients with Hodgkin's disease and testicular cancer are negatively influenced by the occurrence of SMT. Patients with head and neck cancer are predisposed to second tumors by the field cancerization due to tobacco and other carcinogens. Additional factors may be genetic influences, age, and treatment-related factors. Previous studies reported a widely different incidence of second cancer after the diagnosis of head and neck cancer $[6,7]$. Recently, Merlano et al. [8] reported that patients with head and neck cancer treated with chemo-radiotherapy developed more second cancers than patients treated only with radiation. However, in that study, the total survival was still superior in the group of patients treated with chemo-radiotherapy compared to the radiation group. In the present study we investigated the patients treated at our center with combined chemo-radiotherapy for the long-term treatment results, late complications and for the occurrence of SMT.

\section{Patients and Methods}

All patients treated at our center between January 1988 and June 2000 (10 years and 6 months) with combined chemo-radiotherapy were included in the present study. 4 patients were excluded because the records were insufficient, and 3 patients were excluded because of a preexisting malignant tumor. Clinical characteristics of the patients are shown in table 1.78 patients were treated with an intensive protocol combining cisplatinum, 5fluorouracil, folinic acid and hyperfractionated irradiation [1, 2]. The remaining 22 patients were treated with less intensive chemo-radiotherapy, mainly because of age and reduced performance status. In these 22 patients, combinations of 5-fluorouracil and mitomycin- $\mathrm{C}$ were used as chemotherapy.

Before beginning the treatment, 24 patients underwent a surgical tumor reduction (13 patients had radical neck dissection, 2 patients had radical neck dissection and radical tumor surgery, 5 patients had a palliative
Table 1. Patient characteristics

\begin{tabular}{|c|c|}
\hline \multicolumn{2}{|l|}{ Age (years) at diagnosis } \\
\hline Mean \pm SD & $54.55 \pm 8.53$ \\
\hline Median & 54.5 \\
\hline Range & $36-72$ \\
\hline \multicolumn{2}{|c|}{ Follow-up (months after diagnosis) } \\
\hline Mean \pm SD & $26.5 \pm 30.5$ \\
\hline Median & 13.9 \\
\hline \multirow[t]{2}{*}{ Range } & $1-127$ \\
\hline & $\mathrm{n}$ \\
\hline Total number of patients & 100 \\
\hline Females & 11 \\
\hline Males & 89 \\
\hline \multicolumn{2}{|l|}{ UICC stage } \\
\hline II & 2 \\
\hline III & 9 \\
\hline IV & 89 \\
\hline \multicolumn{2}{|l|}{ Site of disease } \\
\hline Oropharynx & 51 \\
\hline Hypopharynx & 24 \\
\hline Larynx & 7 \\
\hline Oral cavity & 9 \\
\hline Other and combined sites & 9 \\
\hline
\end{tabular}

$\mathrm{SD}=$ Standard deviation

tumor reduction, and 4 patients had a palliative tumor reduction and a selective neck dissection). In 3 patients, a tracheostomy was necessary before beginning the treatment.

Fractionated radiotherapy was performed with a cobalt-60 source (Siemens Gammatron-1; patients treated until 9/97) and a linear accelerator (Siemens Linac MD-2; patients treated after 9/97). Treatment planning was individualized by computed tomography. Amifostine was not routinely administered during radiotherapy.

Follow-up was obtained from outpatient records, and by contacting the patient or his physician by telephone. Follow-up was complete in 96 cases (information about clinical status within 12 months of last attempted contact). A complete clinical response was defined as no evidence of disease 3 months after combined treatment. If radiological abnormalities persisted, the patient was evaluated at the next follow-up visit, and was termed complete response if no progression had developed.

Late effects were evaluated if the patient had survived at least 1 year after diagnosis, did not have an SMT, and was available for an interview or if adequate records were present.

The diagnosis of SMT was made if a tumor showed a histology different from that of the initial tumor and/or a clinical presentation of a second unrelated tumor.

\section{Statistical Methods}

Survival, relapse-/progression-free survival and the occurrence of SMT were estimated by Kaplan-Meier analysis. SPSS, version 10, was used for data analysis and statistical calculations. Patients who developed SMT were censored for relapse-/progression-free survival.

38 patients were evaluable for treatment-related late effects (median follow-up 46 months after diagnosis). Dryness of mouth of any degree, hypothyroidism, altered taste, hoarseness were considered as minor complications. Bone necrosis, chronic ulcers, fistulas, nerve lesions, laryngeal or esophageal stenoses were considered as major complications. 
Table 2. Second malignant tumors observed after the treatment of advanced head and neck cancer

\begin{tabular}{lllll}
\hline $\begin{array}{l}\text { Patient } \\
\text { No. }\end{array}$ & $\begin{array}{l}\text { Age } \\
\text { years }\end{array}$ & Sex & Histology & $\begin{array}{l}\text { Interval } \\
\text { (first to second cancer) }\end{array}$ \\
\hline 1 & 65 & $\mathrm{~m}$ & lung cancer (squamous) & 8 months \\
2 & 66 & $\mathrm{~m}$ & colon cancer & 5 months \\
3 & 61 & $\mathrm{~m}$ & lung cancer (adenocarcinoma) & 2 years \\
4 & 45 & $\mathrm{~m}$ & basal cell skin cancer & 8 years \\
5 & 71 & $\mathrm{~m}$ & colon cancer & 6 years \\
6 & 52 & $\mathrm{~m}$ & lung cancer (squamous) & 0 months (synchronous) \\
7 & 48 & $\mathrm{~m}$ & lung cancer (squamous) & 13 months \\
\hline
\end{tabular}

Table 3. Relative and absolute risk of second malignancy following head and neck cancer
Table 4. Late complications observed after the treatment of advanced head and neck cancer

\begin{tabular}{llll}
\hline Category & $\begin{array}{l}\text { Number of cases } \\
\text { observed/ expected }\end{array}$ & $\begin{array}{l}\text { Relative risk } \\
(95 \% \text { conf. interv. })\end{array}$ & $\begin{array}{l}\text { Absolute risk per } \\
10,000 \text { person-years }\end{array}$ \\
\hline All patients & $7 / 1.71$ & $4.09(2.82-7.79)$ & 268.5 \\
Male patients & $7 / 1.57$ & $4.45(2.11-8.47)$ & 305.0 \\
Female patients & $0 / 0.14$ & 0 (n.a.) & n.a. \\
\hline
\end{tabular}

n.a. $=$ Not applicable.

\begin{tabular}{lll}
\hline & $\mathrm{n}$ & $\%$ \\
\hline Total number of patients evaluable & 38 & \\
1) No complications & $0 / 38$ & \\
2) Minor complications & $25 / 38$ & 65.8 \\
3) Major complications & $13 / 38$ & 34.2 \\
Osteonecrosis & 3 & \\
Dependency on tracheal cannula & 3 & \\
Severe nerve lesions & 2 & \\
Other problems (persisting ulcers, severe problems of deglutition, others) & 5 & \\
\hline
\end{tabular}

As a reference data base for the tumor incidence in the general population, the Saarland cancer registry was used (reference year 1996). For the calculation of relative risk of SMT, the categories 141, 143-149, 161 (ICD $9)$ were excluded. Age- and gender-specific incidence rates from the normal population were multiplied by the corresponding person-years of observation to obtain the expected number of tumors. The estimation of relative risk (ratio of observed to expected number of cases) was based on the assumption that the observed number of SMT followed a Poisson distribution. Confidence intervals for relative risks were calculated using exact Poisson limits. The estimation of relative risk is statistically significant if the confidence intervals do not overlap the unity.

\section{Results}

\section{Survival and Relapse-Free Survival}

The total survival rates are shown in figure 1a. At 24 months, the total cumulative survival probability was $51.1 \%$, at 48 months it was $38.7 \%$. If only patients are considered who had an intensive cisplatinum-containing chemotherapy, the total cumulative survival rate was $56.6 \%$ at 2 years and $44.3 \%$ at 4 years. The Kaplan-Meier analysis for these patients in comparison with other chemo-radiotherapy regimens is shown in figure $1 \mathrm{~b}$. If patients are considered who are aged 54 or younger and compared with older patients, the younger patients survived slightly longer than older patients (mean survival time 51 versus 46 months). However, the Kaplan-Meier analysis showed no significant difference between younger ( $<55$ years) and older patients (fig. 1c). No significant difference could also be found for sex, extent of disease (stage III versus stage IV), and location (oropharynx and oral cavity versus larynx and hypopharynx, data not shown). The analysis of relapse- or progression-free survival time is shown in figure 2. The cumulative survival probability at 24 months for relapse- or progression-free patients was $39.9 \%$, at 48 months it was $36.7 \%$. A total of 20 patients survived 4 or more years without evidence of relapse. A complete clinical response was found in 43/76 evaluable patients $(56.6 \%)$.

\section{Second Malignant Tumors}

A total of 7 patients developed SMT (4 lung cancers, 2 colon cancers and one basal cell skin cancer; table 2). The cumulative incidence of SMT is shown in figure 3. After 6 years, a cu- 

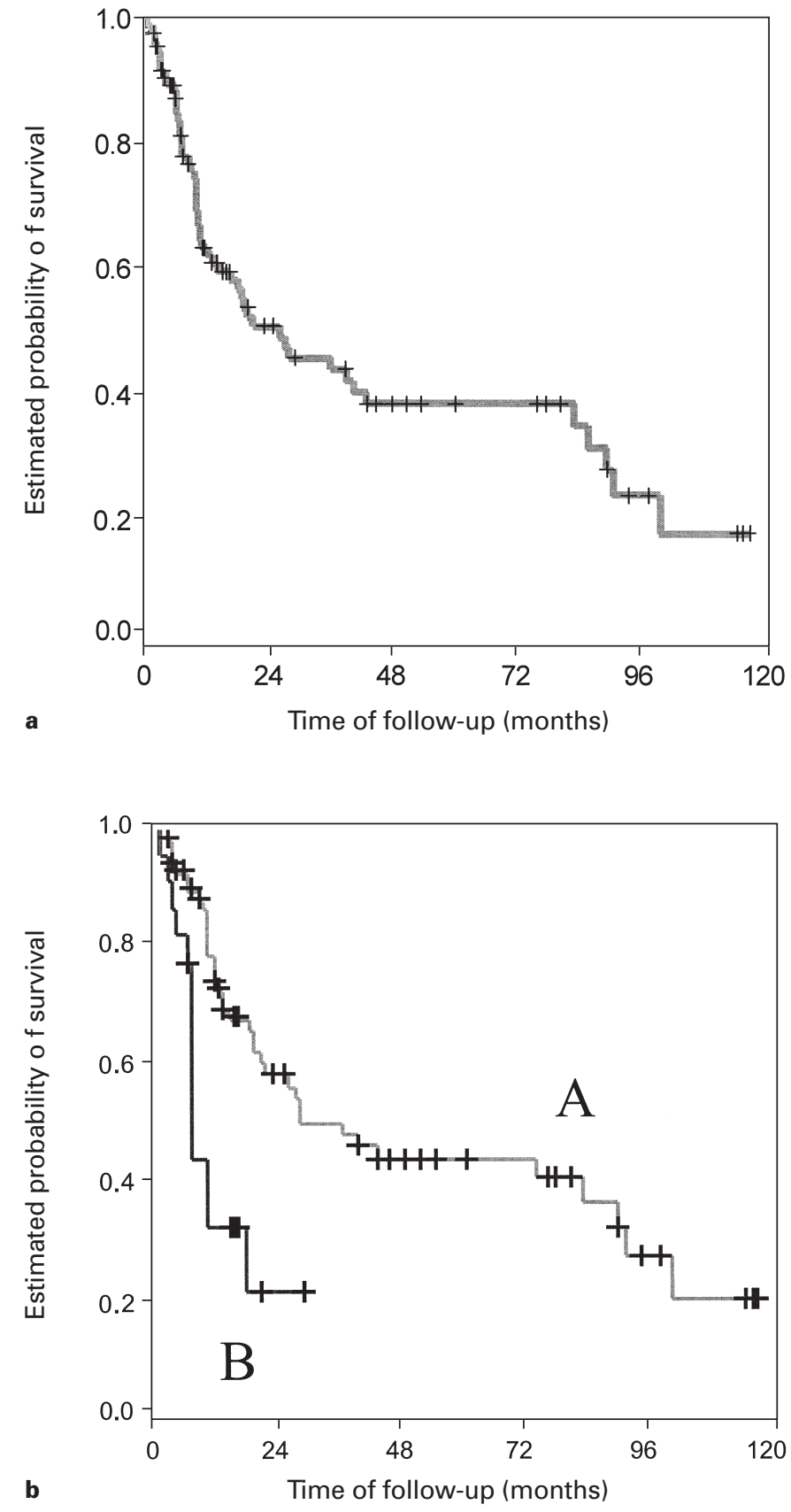

mulative risk of $8.7 \%$, after 8 years a cumulative risk of $16.3 \%$ was observed. All patients with SMT were male. The interval between the diagnosis of head and neck cancer and SMT varied between 0 months and 8 years (median time to diagnosis of SMT: 13 months). In 5 patients the primary head and neck tumor was in remission, in 2 patients active tumor was present. The prognosis of patients with SMT was generally poor: the 4 patients with lung cancer survived $1,2+, 4+$ and 13 months after the diagnosis of SMT, both patients with colon cancer survived only 3 months after the diagnosis of SMT. The relative risk of developing an SMT was significantly increased (4.45-fold in males, 4.09-fold if both sexes are considered) compared with a normal population (table 3 ).

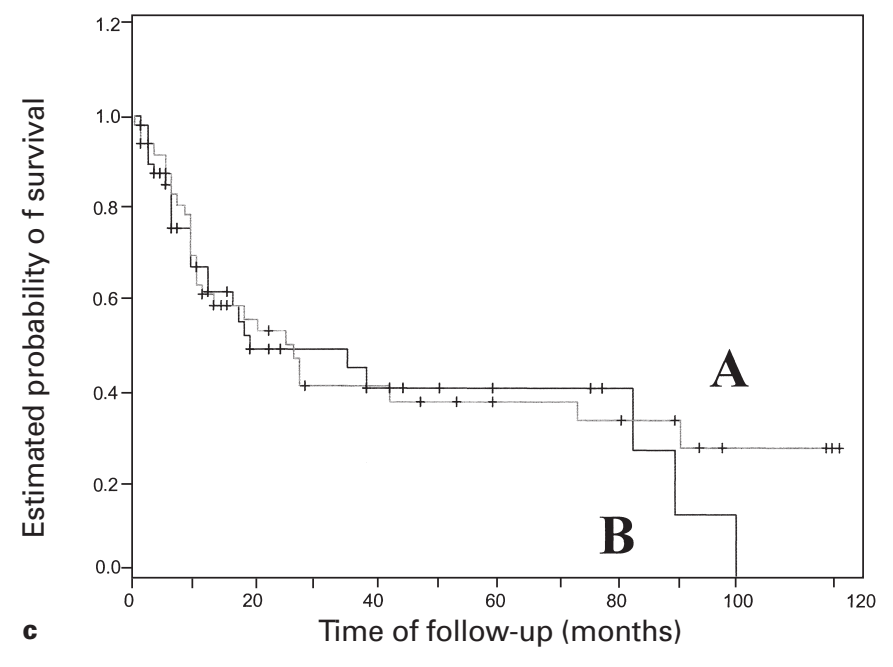

Fig. 1. Total survival rates of patients with advanced head and neck cancer (Kaplan-Meier plots). $-=$ Surviving patients; $+=$ measurement . a Patients treated with chemo-radiotherapy. b Patients treated with chemo-radiotherapy (curve A: patients treated with cisplatinum-based regimen; curve B: patients with other chemotherapy regimens). c Patients treated with chemo-radiotherapy according to age (curve A: patients aged 54 years or younger; curve B: older patients).

\section{Late Complications}

All patients had some degree of functional impairment following chemo-radiotherapy. In $13 / 38$ patients $(34.2 \%)$ major late complications were observed (table 4$)$. If only patients in complete remission and with more than 4 years of follow-up were considered, major complications were seen in 9/19 evaluable patients $(47.4 \%)$.

\section{Discussion}

Our treatment results of chemo-radiotherapy in patients with advanced head and neck cancer are comparable to those from large multicenter and single-center studies [1, 2, 8, 10-12]. Approximately $50 \%$ of patients survived for 2 years, and approximately $35 \%$ survived free from relapse or progression for 4 years. These results were reached despite a majority of stage IV patients and a median age of 54 years. The treatment results published here appear similar to those of a phase II study published a decade earlier [13]; however, in the earlier study only selected patients with a mean age of 47 years were treated. The present results actually show an improvement in the standard of care, most likely due to advances in supportive care. Of all patients who fail treatment, most die from tumor progression, some die from treatment complications or SMT. The development of second, histogenetically unrelated neoplasms is a problem recognized in patients with Hodgkin's disease $[5,10]$ and other good-prognosis tumors like testicular cancer [14], but may also be observed in other tumors. It was 


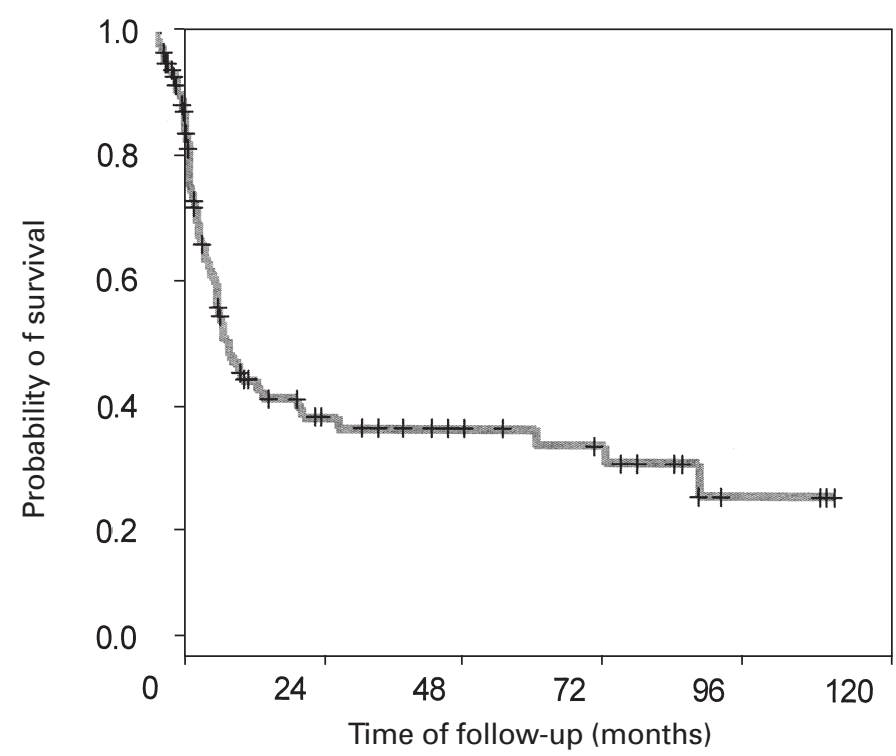

Fig. 2. Relapse- and progression-free survival of patients with advanced head and neck cancer treated with chemo-radiotherapy.

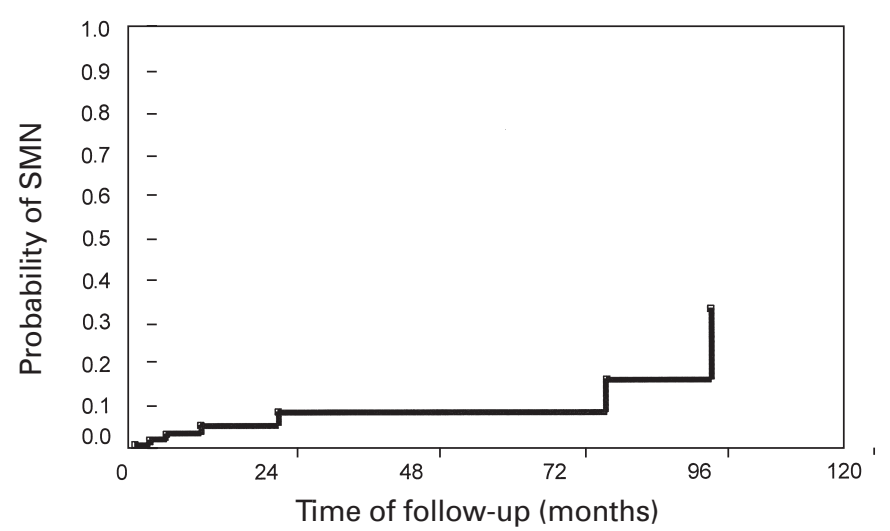

Fig. 3. Cumulative incidence of SMT in patients with advanced head and neck cancer treated with chemo-radiotherapy.

shown earlier that some SMT are related to the treatment administered. In patients with head and neck cancer, the continued influence of carcinogens like tobacco and alcohol may lead to second cancer. Previous studies indicate that $10-30 \%$ of patients develop SMT [6, 7, 15-18]. However, these studies include patients treated in the 1980s, in different stages and with different treatment modalities. Few studies examine patients treated with combined chemotherapy and radiation for their risk of SMT. A list of studies involving chemo-radiotherapy is given in table 5. Our study shows that the risk of SMT is present, and is statistically different from that of the normal population. The type of tumors and the time frame in which these tumors occur indicate that SMT are most likely related to the carcinogens implicated in the primary cancer and are not treatment-related. Typical treatment-related SMT are leukemias following intensive treatment with alkylating agents
Table 5. Risk of second malignant tumors after the treatment of advanced head and neck cancer with chemo-radiotherapy (literature data)

\begin{tabular}{lll}
\hline Study & Cumulative risk & Number of cases \\
\hline Present study & $16.3 \%$ after 8 years & $7 / 100$ \\
SECOG, 1986 [19] & $-^{\mathrm{a}}$ & $-^{\mathrm{a}}$ \\
Franchin et al., 1995 [20] & $-^{\mathrm{a}}$ & $5 / 46$ \\
Merlano et al., 1996 [8] & $7.6 \%$ (no date) & $10 / 80$ \\
Dinges et al., 1997 [21] & $-^{\mathrm{a}}$ & $-^{\mathrm{a}}$ \\
Haffty et al., 1997 [11] & $-^{\mathrm{a}}$ & $12 / 91$ \\
Abitbol et al., 1997 [22] & $-^{\mathrm{a}}$ & $3 / 70$ \\
Brizel et al., 1998 [23] & $-^{\mathrm{a}}$ & $-^{\mathrm{a}}$ \\
Schrader et al., 1998 [12] & $-^{\mathrm{a}}$ & $($ no details) \\
Vokes et al., 2000 [24] & $\approx 15 \%$ at 4 years & $4 / 76$ \\
Jeremic et al., 2000 [25] & $-^{\mathrm{a}}$ & $-{ }^{\mathrm{a}}$ \\
\hline
\end{tabular}

${ }^{\mathrm{a}}$ Not mentioned.

or sarcomas in the field of radiation. Some cases of apparent SMT may actually represent metastasis of the primary cancer. This was shown by microsatellite analysis in 10/16 cases of lung cancer following head and neck cancer [26]. In our series, patients No. 1, 6 and 7 might fall into this category. Even in 2/16 cases of esophageal cancer following head and neck cancer, a clonal relationship to the primary head and neck cancer could be demonstrated [27]. However, the longer survival and possible cure of a fraction of patients treated with chemo-radiotherapy will favor the appearance of SMT. At present, the major problem in advanced head and neck cancer is local relapse and refractory disease, not death from SMT. A prospective comparison with patients who were treated with unique radiation may determine to what extent SMT are influenced by chemotherapy. Laser surgery should also be integrated in the concept of multimodal treatment and may lead to a further improvement in the long-term prognosis [28].

Quality of life issues are increasingly important for patients with head and neck cancer [29, 30]. Most studies focus on acute toxicities, swallowing disabilities, dry mouth, hoarseness, and mouth pain. These studies generally examine the acute treatment period and at most 12 months beyond. Recently, a randomized study in patients with head and neck cancer showed that a radioprotector (amifostine) ameliorates some of the late toxicities (xerostomia) of chemo-radiotherapy [31]. Our study investigated late toxicities like nerve lesions, esophageal stenosis, and osteonecrosis. All patients had some degree of functional impairment. A surprisingly high number of patients (30-40\%) had major late effects. The current aggressive approach has increased the cure rate in advanced head and neck cancer. With longer follow-up, more patients may develop late toxicities. A prospective comparison may determine to what extent late sequelae are due to chemotherapy and radiation. For the optimal quality of life, it is important to recognize, treat and, if possible, prevent these late toxicities. 


\section{References}

1 Hartenstein RC, Wendt TG, Kastenbauer ER, Trott KR: Simultaneous chemo-radiotherapy with 5-FU/folinic acid/cis-platinum and accelerated splitcourse radiation in advanced head and neck cancer. Onkologie 1989;12:30-32.

2 Wendt TG, Grabenbauer GG, Rodel CM, Thiel HJ, Aydin H, Rohloff, R, Wustrow TP, Iro H, Popella C, Schalhorn A: Simultaneous radiochemotherapy versus radiotherapy alone in advanced head and neck cancer: A randomized multicenter study. J Clin Oncol 1998;16:1318-1324.

3 Urba SG: Concurrent chemoradiation for head and neck cancer, ASCO 36. Annual Meeting, Education Brochure 2000, pp 215-218.

4 Pignon JP, Bourhis J, Domenge C, Designe L: Chemotherapy added to locoregional treatment for head and neck squamous-cell carcinoma: Three meta-analyses of updated individual data. Lancet 2000;355:949-955.

5 Munker R, Hiller E, Melnyk A, Gutjahr, P: Second malignant neoplasms: Clinical implications and basic research. Int J Oncol 1996;9:763-776.

6 Licciardello JT, Spitz MR, Hong WK: Multiple primary cancer of the head and neck, esophagus, and lung. Int J Radiat Oncol Biol Phys 1989;17:467-476.

7 Schwartz LH, Ozsahin M, Zhang GN, Touboul E, De Vataire F, Andolenko P, Lacau-Saint-Guily J, Laugier A, Schlienger M: Synchronous and metachronous head and neck carcinomas. Cancer 1994;74:1933-1938.

8 Merlano M, Benasso M, Corvò R, Rosso R, Vitale V, Blengio F, Numico G, Margarino G, Bonelli L, Santi L: Five-year update of a randomized trial of alternating radiotherapy and chemotherapy compared with radiotherapy alone in treatment of unresectable squamous cell carcinoma of the head and neck. J Natl Cancer Inst 1996;88:583-589.

9 Suntharalingam M, Haas ML, van Echo DA, Haddad R, Jacobs MC, Levy S, Gray WC, Ord RA, Conley BA: Predictors of response and survival after concurrent chemotherapy and radiation for locally advanced squamous cell carcinomas of the head and neck. Cancer 2001;91:548-554.

10 Munker R, Grützner S, Hiller E, Aydemir U, Enne W, Dietzfelbinger H, Busch M, Haas R, Emmerich B, Schmidt M, Duhmke E, Holzel D, Wilmanns W: Second malignancies after Hodgkin's disease: The Munich experience. Ann Hematol 1999;78:544-554.

11 Haffty BG, Son YH, Papac R, Sasaki CT, Weissberg JB, Fischer D, Rockwell S, Sartorelli AC, Fischer JJ: Chemotherapy as an adjunct to radiation in the treatment of squamous cell carcinoma of the head and neck: Results of the Yale mitomycin randomized trials. J Clin Oncol 1997;15:268-276.
12 Schrader M, Schipper J, Jahnke K, Stuschke M, Sack H, Budach V: Hyperfraktionierte-akzelerierte simultane Radio-Chemotherapie bei fortgeschrittenen Hypopharynxkarzinomen. HNO 1998;46:140145

13 Wendt TG, Panzer M, Wustrow TPU, Hartenstein $\mathrm{R}$ : Pattern of failure in long-term survivors after radio-chemotherapy for inoperable head and neck cancer. Onkologie 1996;19:419-422.

14 Kollmannsberger C, Hartmann JT, Kanz L, Bokemeyer $\mathrm{C}$ : Therapy-related malignancies following treatment of germ cell cancer. Int J Cancer 1999;83 860-863.

15 Cooper JS, Pajak TF, Rubin P, Tupchong L, Brady LW, Leibel SA, Laramore GE, Marcial VA, Davis LW, Cox JD, et al: Second malignancies in patients who have head and neck cancer: Incidence, effect on survival and implications based on the RTOG experience. Int J Radiat Oncol Biol Phys 1989;17: 449-456.

16 Sturgis EM, Miller RH: Second primary malignancies in the head and neck cancer patient. Ann Oto Rhinol Laryngol 1995;104:946-954.

17 Jones AS, Morar P, Phillips DE, Field JK, Husband D, Helliwell TR: Second primary tumors in patients with head and neck squamous cell carcinoma. Cancer 1995;75:1343-1353.

18 Leon X, Quer M, Diez S, Orus C, Lopez-Pousa A, Burgues J: Second neoplasms in patients with head and neck cancer. Head Neck 1999;21:204-210.

19 SECOG: A randomized trial of combined multidrug chemotherapy and radiotherapy in advanced squamous cell carcinoma of the head and neck. Eur J Surg Oncol 1986;12:289-295.

20 Franchin G, Gobitti C, Minatel E, Barzan L, De Paoli A, Boz G, Mascarin M, Lamon S, Trovo MG Simultaneous radiochemotherapy in the treatment of inoperable, locally advanced head and neck cancers. A single-institution study. Cancer 1995;75 1025-1029.

21 Dinges S, Budach V, Stuschke M, Budach W, Boehmer D, Schrader M, Jahnke K, Sack H Chemo-radiotherapy for locally advanced head and neck cancer - long-term results of a phase II trial. Eur J Cancer 1997;33:1152-1157.

22 Abitbol AA, Sridhar KS, Lewin AA, Schwade JG, Raub W Jr, Wolfson A, Gonzalez-Angulo C, Adessa A, Goodwin WJ, Markoe AM: Hyperfractionated radiation therapy and 5-fluorouracil, cisplatin, and mitomycin-C ( \pm granulocyte-colony stimulating factor) in the treatment of patients with locally advanced head and neck carcinoma. Cancer 1997;80:266-276.
23 Brizel DM, Albers ME, Fisher SR, Scher RL, Richtsmeier WJ, Hars V, George SL, Huang AT, Prosnitz LR: Hyperfractionated irradiation with or without concurrent chemotherapy for locally advanced head and neck cancer. N Engl J Med 1998; 338:1798-1804.

24 Vokes EE, Kies MS, Haraf DJ, Stenson K, List M, Humerickhouse R, Dolan ME, Pelzer H, Sulzen L, Witt ME, Hsieh YC, Mittal BB, Weichselbaum RR: Concomitant chemoradiotherapy as primary therapy for locoregionally advanced head and neck cancer. J Clin Oncol 2000;18:1652-1661.

25 Jeremic B, Shibamoto Y, Milicic B, Nikolic N, Dagovic A, Aleksandrovic J, Vaskovic Z, Tadic L: Hyperfractionated radiation therapy with or without concurrent low-dose daily cisplatin in locally advanced squamous cell carcinoma of the head and neck: A prospective randomized trial. J Clin Oncol 2000;18:1458-1464.

26 Leong PP, Rezai B, Koch WM, Reed A, Eisele D, Lee DJ, Sidransky D, Jen J, Westra WH: Distinguishing second primary tumors from lung metastases in patients with head and neck squamous cell carcinoma. J Natl Cancer Inst 1998;90:972-977.

27 Califano J, Leong PL, Koch WM, Eisenberger CF, Sidransky D, Westra WH: Second esophageal tumors in patients with head and neck squamous cell carcinoma: An assessment of clonal relationships. Clin Cancer Res 1999;5:1862-1867.

28 Sadick H, Riedel F, Bergler W, Hörmann K: Preliminary oncological results of a multimodality regimen with transoral laser surgery, neck dissection and postoperative irradiation in advanced laryngeal carcinomas. Onkologie 2000;23:246-250.

29 List MA, Siston A, Haraf D, Schumm P, Kies M, Stenson K, Vokes EE: Quality of life and performance in advanced head and neck cancer patients on concomitant chemoradiotherapy: A prospective examination. J Clin Oncol 1999;17:1020-1028.

30 Hammerlid E, Taft C: Health-related quality of life in long-term head and neck cancer survivors: A comparison with general population norms. Br J Cancer 2001;84:149-156.

31 Brizel DM, Wasserman TH, Henke M, Strnad V, Rudat V, Monnier A, Eschwege F, Zhang J, Russell L, Oster W, Sauer R: Phase III randomized trial of amifostine as a radioprotector in head and neck cancer. J Clin Oncol 2000;18:3339-3345. 